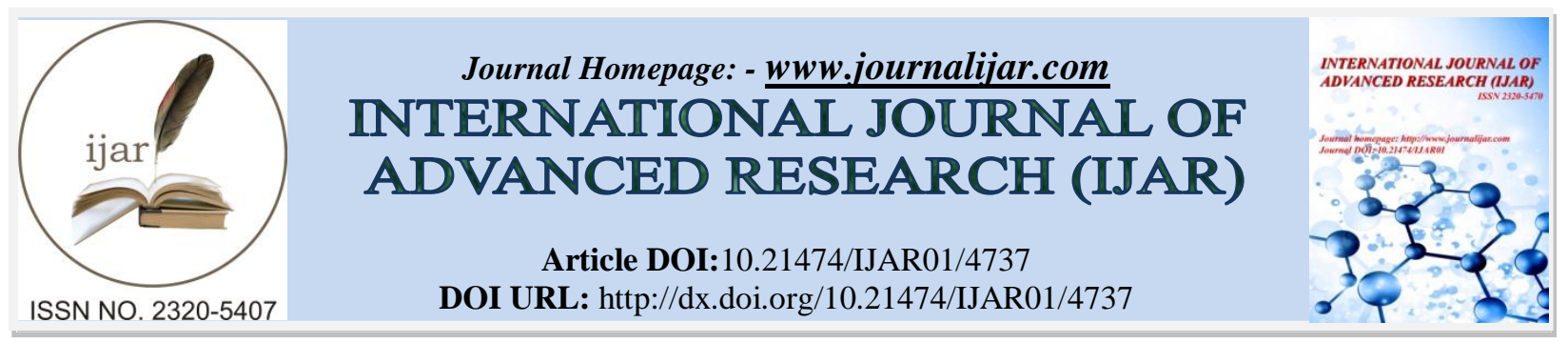

RESEARCH ARTICLE

\title{
ASSESSMENT OF SURFACE AND GROUNDWATER QUALITY FOR PUBLIC HEALTH AND IRRIGATION OF HIGH ALTITUDE AREAS OF HIMACHAL PRADESH, INDIA.
}

\author{
Ravinder Kumar $^{1}$, S.S. Paliyal ${ }^{2}$ and Sanjay Kumar Sharma ${ }^{3}$. \\ 1. Ph. D Doctoral Scholar, Department of Soil Science H.P. KrishiVishavavidyala, Palampur-176062, India. \\ 2. Principle Scientist, (Soil Science) KrishiVigyan Kendra, Sirmour at Dhaulakuan (H.P.) 173031. \\ 3. Principle Scientist, (Soil Science) H.P. KrishiVishavavidyala, Palampur 176062, India.
}

\section{Manuscript Info}

.........................

Manuscript History

Received: 4 May 2017

Final Accepted: 6 June 2017

Published: July 2017

Key words:-

Water quality, high altitude, India

H.P

\section{Abstract}

Some important physico-chemical parameters of surface and groundwater of Spiti Valley of Lahaul \& Spiti Districts were evaluated for the criteria of irrigation water quality. Fifty water samples were collected in the monsoon season (July- August) from different areas of Spiti Valley. The study revealed that temperature, $\mathrm{pH}$, electrical conductivity (EC), higher average value of EC suggests the enrichment of salt due to evaporation effect. $\mathrm{Ca}^{2+}$ is an essential nutritional element for humans and helps in maintaining the structure of plant cells and soils. The higher contribution of $\mathrm{Na}^{+}$than that of the contribution of $\mathrm{Ca}^{2+}$ to the total cations is expected due to influence of ion exchange. The higher concentration of $\mathrm{Na}^{+}$among the cationic concentrations reflects a rock weathering and/ or dissolution of soil salts stored by the influence of evaporation and also indicates its higher solubility behaviour, while the lower concentration of $\mathrm{K}^{+}$is because of its fixation on clay minerals. Any initiative for surface and groundwater development for planned irrigation practices is highly encouraged.

Copy Right, IJAR, 2017,. All rights reserved.

\section{Introduction:-}

There is a growing human population in the world over which directly means an increase in food production, whereas food production to feed this growing population is decreasing everyday which can be associated with poor agricultural practices. The massive growths of human populations and economic development have resulted in the current worldwide deterioration in water quality. Agriculture can have an important impact on the quality of surface water. Water is prime natural resources a basic human need and a precious natural a set. Fresh water resources are used for various purposes, like agricultural, household, recreational, environmental activities. Water is the most vital resources for all kinds of life on the earth and essential for the sustainability of the earth's ecosystem. Fertilizer consumption has strongly increased in all developing countries. In addition to, it affects water quality negatively. Irrigated agriculture is dependent on adequate water supply of usable quality. Water quality concerns have often been neglected because good quality water supplies have been plentiful and readily available (Shamsad and Islam, 2005). Intensive use of nearly all good quality supplies means that new irrigation projects, and old projects seeking new or supplemental supplies, must rely on lower quality and less desirable sources (Cuena, 1989). Irrigation water quality is related to its effects on soils and crops and its management. High quality crops can be produced only by using high-quality irrigation water keeping other inputs optimal. Poor quality of irrigation water affects both soil quality and crop production adversely (Bello, 2001). The poor quality of the irrigation water may affect crop yields 
and soil physical conditions (Talukder et al. 1998). For example, the average yield of wheat decreased by $24 \%$, rice decreased by $39 \%$, vegetables decreased by $30 \%$, and corn decreased by $21 \%$ over normal yield when poor quality water was used. (Lindhjem, 2007). Salt affected soils and water are part of the geochemical processes, soluble salts originate from weathering of minerals and rocks, depending on the chemical constituents of the parent rock. Normally, salts move from the weathering sites into the ground water system, moves into streams and lakes and then into the oceans, if rainfall is high as in humid climates, most salts have been transported into oceans or to deep groundwater system. In arid environments, where rainfall is limited, salts are frequently present in the soil. The major irrigation water is judged by four important measures of salinity hazard, sodium hazard, toxicity hazard and residual sodium carbonate hazard (Michael, 1978). The chemical constituents of irrigation water can affect plant growth directly through toxicity or deficiency, or indirectly by altering plant availability of nutrients (Rowe and Abdel-Magid, 1995).

Fig.1:-Map showing sampling site in Spiti Valley.

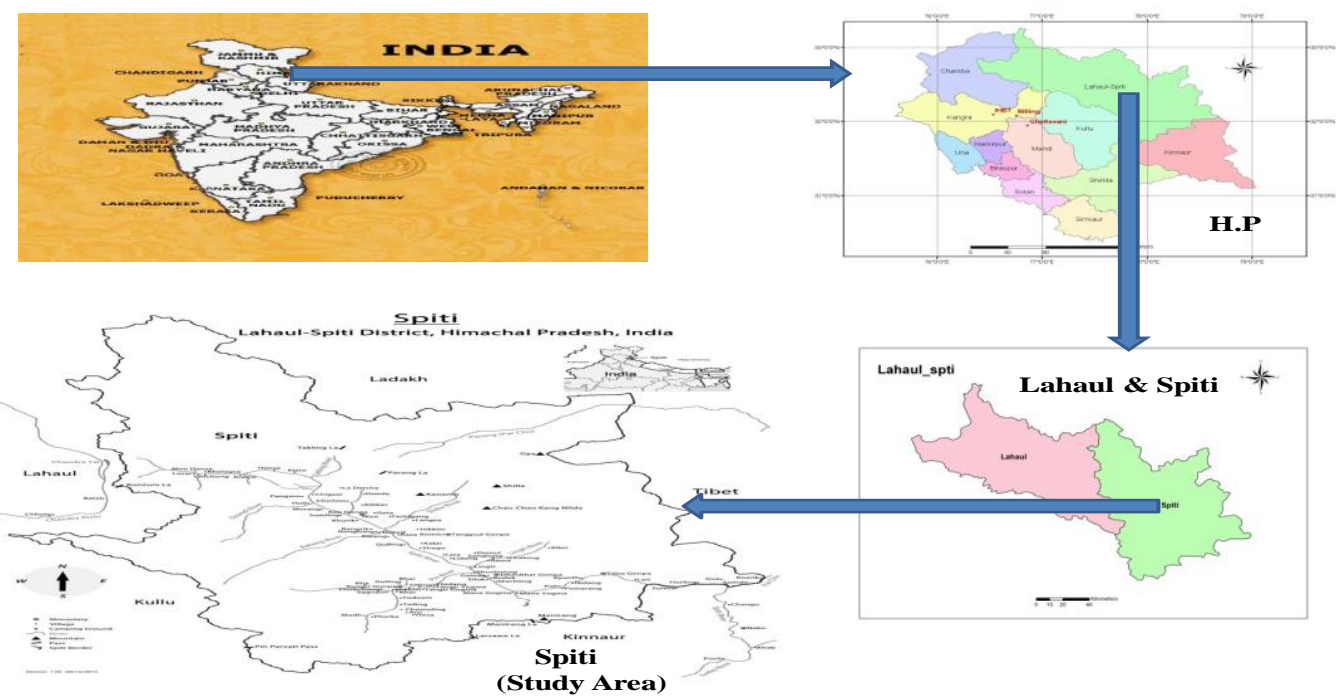

\section{Material and Method:-}

A field research was conducted to evaluate the suitability of groundwater for irrigated agriculture of Lahaul and Spiti District (fig 1.). A total of 50 ground water irrigation public health samples representing extensively used STW and DTW area were collected from various sites in the cropping period of the peak monsoon season (July-August)). Samples were collected from 18 nalahas, 10 hand pumps, 12 chasmas, 5 taps and 5 springs. The high density PVC bottles were used for sampling. They were thoroughly cleaned by rinsing with 8N HNO3 and deionized water followed by repeated washing with water sample as suggested by (De, 1989). Before sampling from a well, water was pumped out sufficiently so that the sample represents the groundwater from which the well is fed (Raghunath, 1987). The bottles were kept air tight and labeled properly for identification. Aeration during sampling was avoided by stoppering the bottle quickly. Various determinants, such as EC, $\mathrm{pH}$ and temperature of the samples were measured on the spot using portable EC-meter, pH-meter and thermometer, respectively. Samples collected from study area were carefully transported to the laboratory and were preserved in a refrigerator for analysis. The analysis for the physico-chemical parameters of the samples were carried out following the established analytical methods. $\mathrm{Na}^{+}$and $\mathrm{K}^{+}$were determined by flame photometry (Jackson, 1967).; Ca2 $2^{+}, \mathrm{Mg} 2^{+}$, Fe and B by visible spectrophotometry (Page et al. 2009).; $\mathrm{Cl}^{-}$and $\mathrm{HCO}^{-3}$ by titration method (Jackson, 1967) ; the sodium adsorption ratio (SAR) was estimated by the equation using the values obtained for, $\mathrm{Ca}^{2+}, \mathrm{Mg}^{2+}$ in me/I (Richards, 1954).; the soluble sodium percentage (SSP) was determined by the equation using the values obtained for $\mathrm{Na}^{+}, \mathrm{K}^{+}$, Ca $2^{+}$, $\mathrm{Mg}^{2+}$ in me/l (Todd, 1980). Carbonate and bicarbonate concentrations were measured by acid-base titration. Sulphate and nitrate concentrations were measured by using colorimetric-spectrophotometer. The accuracy of the analysis for major ions was cross checked from the ionic balance was within $\pm 7 \%$ for all the samples, ions were converted from milligram per litre to milliequivalent per litre. 


\section{Results and Discussion:-}

In the present study area, the cation-anion balance is computed for accuracy of complete chemical analysis of groundwater sample. The computed value of the cation-anion balance is observed to be within the limit of $\pm 5 \%$, thus confirming the accepted range of hydrogeo-chemical values. The statistical data is given in table 2 . The $\mathrm{pH}$ in the groundwater is varied from 7.2 to 7.9. The value of EC is a measure of a material's ability to conduct an electric current and varies from 495 to $3054 \mu \mathrm{S} / \mathrm{cm}$ (Table 2). The higher average value of EC suggests the enrichment of salt due to evaporation effect. According to the classification of EC, $70.3 \%$ of the total groundwater samples come under the type low enrichment of salts $(\mathrm{EC}<1,500 \mu \mathrm{S} / \mathrm{cm}), 28.1 \%$ under the medium enrichment of salts (EC: 1,500 and 3,000 $\mu \mathrm{S} / \mathrm{cm}$ ), and only one sample of Spiti village under high enrichment of salts $\{\mathrm{EC}>1,500 \mu \mathrm{S} / \mathrm{cm}\}$ (Kelly, 1963). The carbonate $\left(\mathrm{CO}_{3}{ }^{2-}\right)$ varied from 57 to $198 \mathrm{mg} / \mathrm{L}$ and bicarbonate is varied from 139 to $276 \mathrm{mg} / \mathrm{L}$. Excessive concentrations of dissolved ions such as $\mathrm{HCO}_{3}^{-}$and $\mathrm{CO}_{3}{ }^{2-}$ present in the irrigation water affect plants and agricultural soil physically and chemically through lowering of osmotic pressure in the plant structural cells (Thorne and Peterson, 1954). The dominant cations are in the order of $\mathrm{Na}^{+}>\mathrm{Ca}^{2+}>\mathrm{K}^{+}>\mathrm{Mg}^{2+}$. $\mathrm{The}^{+} \mathrm{Na}^{+}$concentrations are ranging between 79 and $140 \mathrm{mg} / \mathrm{L}$ with average of $105.38 \mathrm{mg} / \mathrm{L}$. The concentration of $\mathrm{Na}^{+}$(Average $105.38 \mathrm{mg} / \mathrm{l}$ ) is higher than that of $\mathrm{K}^{+}$(Average $74.03 \mathrm{mg} / \mathrm{l}$; Table 2). The higher concentration of $\mathrm{Na}^{+}$among the cationic concentrations reflects a rock weathering and/or dissolution of soil salts stored by the influence of evaporation and also indicates its higher solubility behaviour, while the lower concentration of $\mathrm{K}^{+}$is because of its fixation on clay minerals (Stallard and Edmond, 1983; Hem, 1991). The $\mathrm{Ca}^{2+}$ and $\mathrm{Mg}^{2+}$ are the most abundant elements in the groundwater. The concentration of $\mathrm{Ca}^{2+}$ is between 11 and $121 \mathrm{mg} / \mathrm{L}$, while that of the concentration of $\mathrm{Mg}^{2+}$ is varied from 39 to $89 \mathrm{mg} / \mathrm{L}$. $\mathrm{Ca}^{2+}$ may dissolve readily from carbonate rock and limestone or be leached from soil. However, the dissolved $\mathrm{Mg}^{2+}$ concentration is lower than $\mathrm{Ca}^{2+}$ in the groundwater. $\mathrm{Ca}^{2+}$ is an essential nutritional element for humans and helps in maintaining the structure of plant cells and soils. The higher contribution of $\mathrm{Na}^{+}$ than that of the contribution of $\mathrm{Ca}^{2+}$ to the total cations is expected due to influence of ion exchange. The Chloride levels shown in Table 2 are; $0.10 \mathrm{mg} / \mathrm{L}$ to $1.19 \mathrm{mg} / \mathrm{L}$ respectively. According to the any water with a chloride value above $10 \mathrm{mg} / \mathrm{L}$ is considered harmful for both domestic and agricultural purposes (WHO, 1997). Therefore, the water at the study area falls far below those considered harmful by WHO standard. However, considering the mobility of Chlorides also and some domestic activities taking place in the surface stream water, there is every possibilities that it's level may increase with time, as it can be noted in the values for both nalaha and surface handpump water as analyzed in this work as $0.89 \mathrm{mg} / \mathrm{L}$ and $1.19 \mathrm{mg} / \mathrm{L}$ respectively. The content of $\mathrm{SO}_{4}{ }^{2-}$ is observed from 23 to $65 \mathrm{mg} / \mathrm{L}$. $\mathrm{SO}_{4}{ }^{2-}$ is a naturally occurring ion in almost all kinds of water bodies and is a major contributor to total hardness. $\mathrm{SO}_{4}{ }^{2-}$ content more than $200 \mathrm{mg} / \mathrm{l}$ is objectionable for domestic purposes; beyond this limit, $\mathrm{SO}_{4}{ }^{2-}$ causes gastro-intestinal irritation (Elhatip et al. 2003).

Table 1:- Classification of water based on irrigation indices.

\begin{tabular}{|l|l|l|l|l|l|l|l|}
\hline SAR & Class & RSC & Class & PI & Class & Na\% & Class \\
\hline$<10$ & Excellent & $<1.25$ & Safe & $75 \%$ & Class I & $<20$ & Excellent \\
\hline 10 to 18 & Good & $1.25-2.5$ & Marginal & $75 \%$ & Class II & $20-40$ & Good \\
\hline 18 to 26 & Fair & $>2.5$ & Unsuitable & $25 \%$ & Class III & $\begin{array}{l}40-60 \\
60-80\end{array}$ & $\begin{array}{l}\text { Permissible } \\
\text { Doubtful }\end{array}$ \\
\cline { 6 - 8 } & & & & & & $>80$ & Unsuitable \\
\hline
\end{tabular}

Table2:-Stastical data of the surface groundwater samples of study area.

\begin{tabular}{|c|c|c|c|c|c|c|c|c|c|c|}
\hline & $\mathbf{p H}$ & $\mathbf{E C}$ & $\mathbf{C O}_{\mathbf{3}}{ }^{2-}$ & $\mathbf{H C O}$ & $\mathbf{K}^{+}$ & $\mathbf{C a}^{+2}$ & $\mathbf{M g}^{\mathbf{2}}$ & $\mathbf{N a}^{2+}$ & $\mathbf{C l}^{-}$ & $\mathbf{S o}_{\mathbf{4}}{ }^{2-}$ \\
\hline Mean & 7.6 & 1160.70 & 101.60 & 208.58 & 74.03 & 89.90 & 71.60 & 105.38 & 0.61 & 35.56 \\
\hline Minimum & 7.2 & 495 & 57 & 139 & 0.20 & 11 & 39 & 79 & 0.10 & 23 \\
\hline Maximum & 7.9 & 3054 & 198 & 276 & 121 & 121 & 89 & 140 & 1.19 & 65 \\
\hline SD & 0.12 & 689.88 & 32.28 & 32.80 & 34.59 & 17.14 & 12.57 & 15.18 & 0.30 & 8.90 \\
\hline
\end{tabular}

Units are expressed in $\mathrm{EC}(\mu \mathrm{S} / \mathrm{cm})$; except all are in $\mathrm{mg} / \mathrm{L}$

\section{Acknowledgement:-}

The authors are highly thankful to Soil Science Department, CSK H.P.K.V, Palampur, Soil PG Lab assistant for heartfelt help and coordinal support in guiding the authors in a right direction. 


\section{Literature Cited:-}

1. Bello, S. 2001. B.Sc. Project. Department of Soil Science and Agricultural Engineering,UsmanDanfodio University, Sokoto. 69-70

2. De, A.K. 1986. Environmental chemistry wiley-quality rating of groundwater in south India,symp. (int). Development of groundwater resources, Madras, 3:1-8

3. Elhatip, H., Afsin, M., lkayKusçu, K., Dirik, Y., Kurmaç, M., Kavurmaci. 2003.Irrigationtheory and practice. Vikas Publishing House Pvt.Ltd, New Delhi, pp. 713-713.

4. Hem, J.D. 1985. Study and interpretation of the chemical characteristics of natural water (3d ed.): U.S. Geological Survey Water-Supply Paper 2254, 263 p.

5. Jackson, M.L. 1967. Soil chemical analysis. Prentice Hall, India Pvt. Ltd., New DelhiKelly, W.P. 1963. Use of Saline Irrigation Water. Soil Sci. 95(4):355-39

6. Lindhjem, H. 2007. Environmental Economic Impact Assessment in China: Problems andProspects. Environ. Impact Assess. Rev. 27(1):1-25

7. Michael, A.M. 1978. Irrigation Theory and Practice. Vikas Publishing House Pvt.Ltd, New Delhi, pp. 713-713.

8. Page, M., Joshi, D.M., Kumar, A., Agrawal, N. 2009. Assessment of the Irrigation Water Quality of River Ganga in Haridwar District, India. J. Chem. 2(2):285-292.

9. Raghunath, H.M. 1987. Groundwater, 2nd Ed. Wiley Eastern Ltd. New Delhi, India, pp. 344-369.

10. Richards, L.A. 1954. Diagnosis and Improvement of Saline and Alkali Soils. USDA and IBH Pub, Coy Ltd., New Delhi, India. Agric. Handbook 60:98-99.

11. Rowe, D. R. and Abdel-Magid, I. M. 1995. Hand Book of Wastewater Reclamation and Reuse," CRC Press Inc. 550

12. Shamsad, S.Z.K.M. and Islam, M. S. 2005. Hydrochemical behavior of the water resource of Sathkhira Sadar of south western Bangladesh and its impact on environment.

13. Bangladesh Journals of Water Resource Research. 20: 43-52

14. Stallard, R. F., and J.M. Edond. 1983. Evaluation of Groundwater quality and its suitability for domestic and irrigation use in Parts of the Chandauli-Varanasi Region, Uttar Pradesh, India. Pp123-132

15. Talukder, M.S.U., Shirazi, S.M., Paul, U.K. 1998. Suitability of Groundwater for Irrigation at Kirimganj Upazila Kishoreganj. Progress Agric. 9:107-112.

16. Thorne, D.W. and Peterson, H.B. 1954. Irrigated Soils. Constable and Company Limited, London, 113.

17. Todd, D.K. 1995. Groundwater hydrology. John Wiley and Sons Publications, 3rd Ed, New York.

18. WHO. 1997. Guideline for drinking water quality. 133. 